\title{
Hoax Digital Literacy on Instagram
}

\author{
http://dx.doi.org/10.25008/jkiski.v6i2.581
}

\author{
Dedeh Fardiah $^{1}$, Ferry Darmawan $^{2 *}$, Rini Rinawati ${ }^{3}$ \\ ${ }^{1,2,3}$ Faculty of Communication Science, Universitas Islam Bandung \\ Jl. Tamansari No. 1, Bandung 40116 - Indonesia \\ *Corresponding author: ferry@unisba.ac.id
}

Submitted: June 12, 2021, Revised: September 15, 2021, Accepted: October 09, 2021

Accredited by Kemristekdikti No. 28/E/KPT/2019

\begin{abstract}
The development of communication technology brings forth new media with various multiplatforms. Information spreads instantaneously to all corners of the world through abundant media devices. In social media spaces, every individual can produce informational content and disseminate it, so it appears as a new phenomenon of citizen journalism. Individuals act as both producers and targets of social media content simultaneously. Ironically, due to freedom of expression on social media, various hoaxes appear intentionally or unintentionally and are widely distributed. This study aims to explore the official Instagram account that handles hoaxes in West Java Province and provide a digital literacy education in their post. This study uses the content analysis method, which efficiently investigates media content on both printed form and digital posts. In addition, it also uses descriptive content analysis to describe in detail a message or a specific content. The study object is Instagram @jabarsaberhoaks with an analysis unit of information items about hoaxes and various digital literacy on Instagram @jabarsaberhoaks in 2020. In total, their number reaches 900 posts. The result of this study shows that the most common hoax is fake news, such as manipulated content, misleading content, fake news, and fabricated content with health, political, and economic themes. Explicitly or implicitly, digital literacy education about hoaxes can be obtained by accessing the information contained in Instagram accounts. The implication is that it is necessary to study the extent of this educational content responded by the public, so media messages can effectively and efficiently be in the form of educational media about interactive hoaxes.
\end{abstract}

Keywords: Misleading; content analysis; @jabarsaberhoaks; fake news; fabricated.

\section{Introduction}

Indonesia is a country that has high accessibility to media exposure. The Indonesian public consumes media in various forms every day, including print, electronic, and online media. However, this condition is not always in line with the public ability to digest media, especially online media. Many people do not have digital literacy capabilities, even though digital literacy skills are essential in anticipating media impacts. The development of social media raises the hoax phenomenon more, along with the development of digital technology. Recent studies on hoaxes explain that social media and the internet have changed the way hoaxes are spread. It is caused by the speed of information dissemination and public connectivity. Virtual environment makes it faster and easier to share viral news without checking for accuracy. Once false rumours are intentionally spread to the public widely, it is almost impossible to correct them. (Kasperek \& Messersmith, 2015)

In 2019, the Ministry of Communication and Informatics of the Republic of Indonesia released data of 4,041 hoax issues that spread in Indonesia. Even in a time of Coronavirus Disease (Covid-19) outbreak, an infodemic emerged. In 2020, a total of 2.020 contents were identified as hoaxes circulating on social media. 
Of the total, 1,197 come under the topic category. The Ministry of Communication and Informatics has taken down 1,759 out of 2.020 hoax contents. (Ministry of Communication and Informatics Press Release, 19/10/2020). The rapid spread of hoax contents has become cause for major concern in the public. According to the Edelman Trust Barometer survey (Edelman, 2019), seven out of ten people in the world were worried that fake news would be used as a "weapon." In Indonesia, 76 to 80 percent of the public were worried about the potential for the abuse of hoax contents as a weapon to create domestic instability. Public anxiety does not correlate with hoaxes which are spreading more rapidly through social media.

In fighting hoaxes, the government has made efforts, including enacting Electronic Information and Transaction (ITE) Law in 2018 and forming a National Cyber Agency. Even the Ministry of Communication and Informatics has intensified digital literacy efforts to deal with the spread of hoaxes. In providing digital literacy education (Rahmah, 2015) learning system model of digital literacy can be applied based on the knowledge built with characteristics of Indonesia. The digital divide in Indonesia requires digital literacy education delivered through several mechanisms of knowledge transfer. Family guidance and digital literacy education must follow the code of ethics given by citizens' beliefs and create a detailed curriculum in educational institutions.

In the context of West Java, a West Java Hoax Buster (JSH) was formed in 2018. Materials with hoax content are analyzed by Hoax Analyzer by processing reports received from the public. In 2019, JSH clarified 2.643 complaints from a total of 4,454 complaints. In 2020, JSH socialized its activities in 13 Cities/Regencies in West Java. In 2019, JSH managed to get an $8,360,402$ social media page organic reach through clarifying content and digital literacy. It received hundreds of thousands of comments and likes as a form of public response. In 2020, the researcher conducted a study on "JSH Media Literacy Strategy in Minimizing the Spread of Fake News on Social Media." The results of the study indicate that the strategy adopted by this team is to monitor, receive complaints, and educate the public. This study only sees the aspect of JSH as an institution that handles hoax issues. (Fardiah et al., 2020) West Java Hoax Buster also uses communication strategy on social media to sweep up hoaxes by creating content about wise education using social media and content to clarify information, including disinformation, misinformation, or malinformation. The content is made as attractive as possible according to millennials' style and digital natives but still has the characteristics of West Java Hoax Buster. The content is based on public complaints and the results of the team's monitoring which are processed to check the facts and then make a visual image to be posted on social media (Aviani, 2020)

In minimizing hoax news, the role of social media, on the one hand, is to become a very massive hoax spreader. However, on the other hand, social media can be used as a medium for digital literacy education, for example, in online community groups. In the study that has been done, information literacy and discussion about hoaxes wake up in a group of Indonesian Hoaxes. Everybody can ask, discuss, and clarify a hoax in online media. Admin also community members have a role in providing information (Juditha, 2019).

Furthermore, social media can also help visualize hoaxes, such as in a comic strip. Instagram content can explicitly carry the mission of eradicating hoaxes, along with tips and strategies that apply to all walks of life. The implied meaning associated with digital literacy competence in selecting, understanding, analyzing, verifying, evaluating, and distributing what each person needs can be contained on Instagram as a provision to combat hoaxes. (Muda \& Monggilo, 2020) information content making shared in an Instagram account is essential to build digital literacy. It is not just combining two or more different sources to produce original works but also having creative skills, knowing communication culture until communicate content according to the target audience, and critical content that can stimulate mindsets. (Wahyudin \& Adiputra, 2019) A significant and robust relationship between Instagram social media and media literacy skills have been studied. When the utilization of social media Instagram is a good category in line with that, then media literacy skills are in an outstanding category. (Kurnia et al., 2018) Hence, G.P. Swanepoel, in his study, said that Instagram could be effective learning media if put into good use (Swanepoel \& Bruwer, 2020).

The study has been conducted about social media, Instagram, digital literacy, and specifically West Java Hoax Buster, which recently conducted a research on the aspects of utilizing online communities, utilizing comic strip content, providing general information on Instagram in educating the public, describes a 
correlation between Instagram and digital literacy. However, it is specifically about JSH's Instagram content. It only mentions the process of creating Instagram content rather than the substance of digital literacy education that appears in its Instagram content, especially regarding types of hoaxes that develop. This study is what the researcher wants to examine in this study. One of the topics is not explored deeply about clarification of types of hoaxes that develop in the public to provide digital literacy education. Therefore, this study aims to describe hoaxes in the public domain. Thus, the question of this study is, "how does Instagram @jabarsaberhoaks conduct digital literacy education regarding various hoaxes?"

\section{Theoretical Framework}

Nowadays, media technology has taken part in specific roles in the public. Along with communication technology development, there are some positive or negative consequences regarding the influence of communication media technology. According to (Stanley J. Baran, 2010), media affect public culture in various ways. So do not be surprised if our public alive nowadays cannot be separated by the presence of communication media technology. Social media gives online network service facilities to connect people individually or in groups (Dimas et al., 2017). Utilizing social media actively tends to have a positive impact; passive social media harms the possibility of community presence (Dimitrova \& Bystrom, 2017).

The result of this study explains that the context of contents moderate social media content's effectivity on user involvement. The findings of this study contribute to understanding the involvement and experience of social media users. This study is a pioneer to empirically assess the behavioral construction of social media involvement through the effects of content type and context on social media platforms (Shahbaznezhad et al., 2021). Social media's functionality level can configure identity improvement, conversation, share, presence, relation, reputation, and group (Kietzmann et al., 2011). Social media can take a central role in learning in an informal environment where social media offer individual learning informally. In this process, an individual can connect to learning knowledge informally by digesting media content actively (Russo et al., 2009).

One of the popular social media platforms is Instagram, which has the same function as
Twitter, but the difference lies in taking photos in a form or place to share information with users (Atmoko, 2012). Instagram has a significant role in developing an online community particularly in spreading information, increasing quantity, and promoting community popularity (Gumilar \& Kusmayadi, 2017). It can be utilized as supporting media of guidance service and technology-based counseling (Noviyanti, 2020). It also has a social movement attracting social media users' sympathy, empathy, and attention as an early stage of a social movement (Yuliarti et al., 2020). Explanation about content analysis has been done that as content an Instagram can increase the country's branding (Acuti et al., 2018). Content that has credibility shown on Instagram posts positively affects message credibility and attitude towards what it promotes (Lee \& Kim, 2020).

With various weaknesses and advantages, Instagram can be utilized to provide helpful information to the public, for example, in providing media literacy education. Information and media literacy optimize the process of empowering people to find, evaluate, use, and create information effectively in order to achieve their personal, social, occupational, and educational goals. Dimensions in literacy itself conceptualize (1) Access and media user; (2) Media languages and critic understanding; (3) Production Process and Programming; and (4) Situation changes someone based on communication (Cuervo Sánchez et al., 2019). Media literacy responds to counter the adverse effects of mass media and popular culture (Hobbs, 2011).

The roles of digital literacy in strengthening citizens' resilience to misinformation and 'fake news' have been the subject of research projects and networking and academic and policy discourse in the US and UK. Field of media and digital literacy education is realized, for example, by exploring the study of political and economic context for hoaxes, level of credibility of hoaxes to the risk of solutionism in education ecosystem regarding hoax news (McDougall et al., 2019). Obstacles were found in fighting hoaxes, although all parties have made various efforts on international and national scales, both in the form of tools such as Hoax Analyzer and App applications. On a global scale, anti-hoax movement involves Google News Laboratory and First Draft. The movement against hoaxes is carried out by combining technology and human cognition to verify such information. 
Most of which are still formal and have not touched the root of the problem. Various activities and programs initiated by many parties must complement each other and encourage community participation. Therefore, Combating hoax contents is not just about distinguishing what is a hoax and what is not. It is more about identifying how far hoaxes go in the information (Nurlatifah, 2019).

Aside from that, remember that a piece of ample information flowing in a digital environment is highly volatile on social media timelines, enabling an organization's factchecking may not be enough. Thus, social media platforms, traditional media, and institutions must adopt a more "humanfocused" approach, instilling in people to spend more time and cognitive effort dealing with legitimate sources before accepting information as truth (Di Domenico \& Visentin, 2020). One of the roles of digital literacy is combating hoax news that develops in the public, fabricated news, and intentionally intended to mislead or deceive. Fake news usually appears on sites disguised as genuine news sites, although they are often picked up and re-circulated by mainstream media. Efforts to anticipate the widespread circulation of hoaxes need to be accompanied by increased information literacy because the public is the central controller of information flow. Indonesia's public tend to be faster to believe news without confirming the truth and immediately spread it on social media (Juditha, 2019). Hoaxes can be prevented by developing massive digital literacy skills, including critical digital literacy skills (critically addressing content) (Tsaniyah \& Juliana, 2019). Developing and supporting media literacy efforts is critical to rebuilding trust and combating the influence of fake news on public opinion. By understanding hoaxes on social media and fake news, it is hoped that the public will be educated (Finneman \& Thomas, 2018).

Current research shows that fake news is considered a threat to information security. Fake news interferes in users' ability to distinguish helpful information from Internet services, especially when news is essential for decision making (Aldwairi \& Alwahedi, 2018). Hoaxes often succeed in deceiving because they are framed and conveyed intensely, with certain motives that have a public dimension and provoke people who are the target of hoaxes. Therefore hoaxes are included in a type of deconstruction that works as if legitimized information (Fleming \& O'Carroll, 2010). A research conducted in America shows that individuals with a low level of issue knowledge but have a high level of issue involvement tend to believe social media hoaxes and hoaxes that seem convincing cause individuals to engage in active, communicative activities (Park \& Rim, 2020). Spreading hoaxes is one of the media strategies carried out by certain advocacy groups (Veil et al., 2012). Hoax takes advantage of others. Some groups spread hoaxes intentionally to attract public attention and gain public support. Others do it unintentionally. However, some groups also spread hoaxes without realizing that information was inaccurate. Hoaxes that are spread accidentally often occur because not all people have adequate knowledge about a piece of information. Ordinary people, for example, can spread inaccurate data naturally without realizing it (Kata, 2010). It is undeniable that the strategy of using hoaxes is often effective in maximizing attention. Moreover, exposure to hoaxes can manipulate inactive publics and cause them to use heuristic decision-making to solve cursory processing of oversimplified problems and related problems (van der Linden et al., 2015). Therefore, this hoax can motivate them to engage in related issues instantly. 


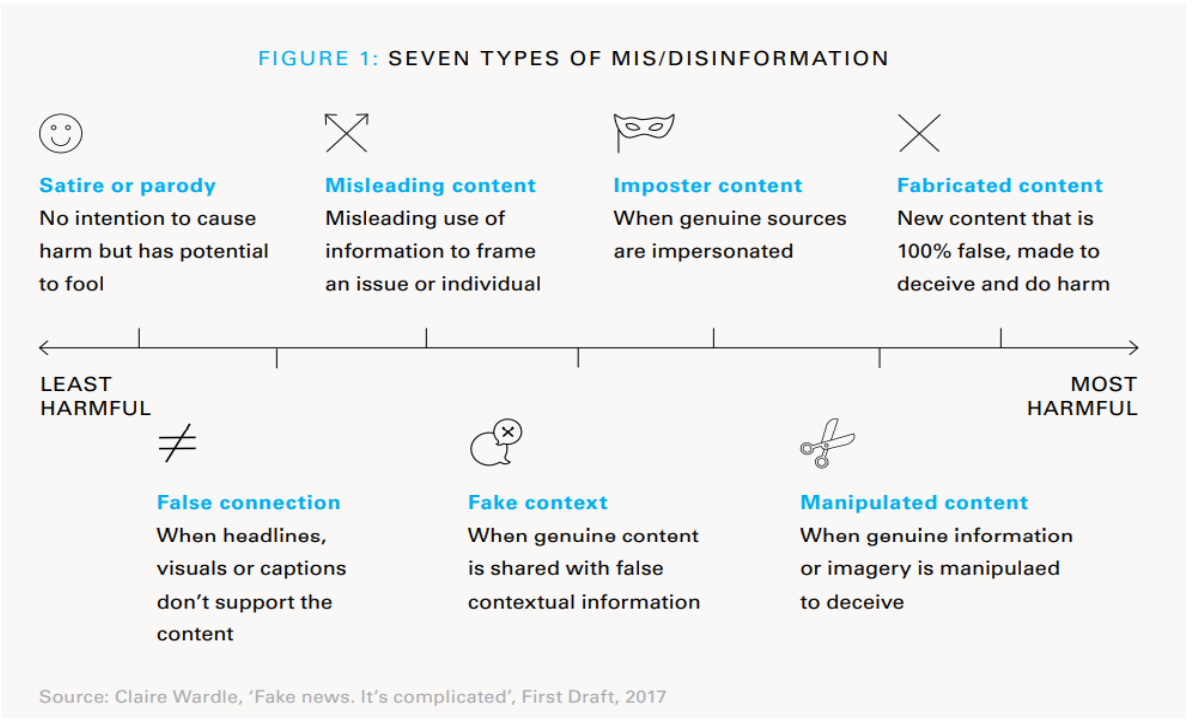

Figure 1. Seven Types of Mis/Disinformation

\section{Material and Methodology}

The study uses a quantitative content analysis method intended to describe content characteristics and draw inferences from content. In this study, content analysis is intended to identify systematically communication content that appears (manifest) and is done by objective, valid, reliable, and replicated (Eriyanto, 2012). The content analysis method efficiently investigates media content, both print and broadcast (Bungin, 2011). In addition, this study also uses descriptive content analysis to describe in detail a message or a specific text. This content analysis design is not intended to test a particular hypothesis or test the relationship between variables. Content analysis is only for description, describing aspects and characteristics of a message. The content aspect to be analyzed refers to the type of misinformation/disinformation from the First Draft. Misinformation/disinformation can appear as text, images, video, and audio, or a combination of these, and is created or manipulated by humans such as by 'deep fakes or created synthetically by supporting tools, so they are grouped into following categories depicted on Figure 1 (Howard \& Neudert, 2021).

The object of this study is Instagram @jabarsaberhoaks containing images or information related to digital literacy contained in their account. The analysis unit in this study is information about digital literacy for Instagram posts@jabarsaberhoaks in 2020. Meanwhile, the unit of measurement in this study is the frequency of occurrence and type of digital literacy content as mention on Table 1.

Table 1. Studi Analysis Categorization

\begin{tabular}{|c|c|c|}
\hline No. & Classification & Analysis Unit \\
\hline 1. & $\begin{array}{l}\text { Satire or } \\
\text { Parody }\end{array}$ & $\begin{array}{l}\text { No intention to cause } \\
\text { harm but has the } \\
\text { potential to fool }\end{array}$ \\
\hline 2. & $\begin{array}{l}\text { Misleading } \\
\text { Content }\end{array}$ & $\begin{array}{l}\text { Use of information to } \\
\text { frame an issue or } \\
\text { individual }\end{array}$ \\
\hline 3. & $\begin{array}{l}\text { Imposter } \\
\text { Content }\end{array}$ & $\begin{array}{l}\text { When genuine sources } \\
\text { are impersonated }\end{array}$ \\
\hline 4. & $\begin{array}{l}\text { Fabricated } \\
\text { content }\end{array}$ & $\begin{array}{l}\text { New content that is } 100 \\
\% \text { false made to deceive } \\
\text { and do harm }\end{array}$ \\
\hline 5. & $\begin{array}{l}\text { False } \\
\text { connection }\end{array}$ & $\begin{array}{l}\text { When headlines, } \\
\text { visuals, or captions do } \\
\text { not support the content }\end{array}$ \\
\hline 6. & Fake news & $\begin{array}{l}\text { When genuine content } \\
\text { is shared with false } \\
\text { contextual information }\end{array}$ \\
\hline 7. & $\begin{array}{l}\text { Manipulated } \\
\text { content }\end{array}$ & $\begin{array}{l}\text { When genuine } \\
\text { information or imagery } \\
\text { is manipulated to } \\
\text { deceive }\end{array}$ \\
\hline
\end{tabular}

After the researcher collected data related to the theme and discussion, as seen in the analysis unit, the researcher classified, processed, and interpreted data. In this study, the researcher wants to know what digital literacy educational messages are contained on Instagram@jabarsaberhoaks. In analyzing research data, elements of digital literacy education in Instagram content were analyzed 


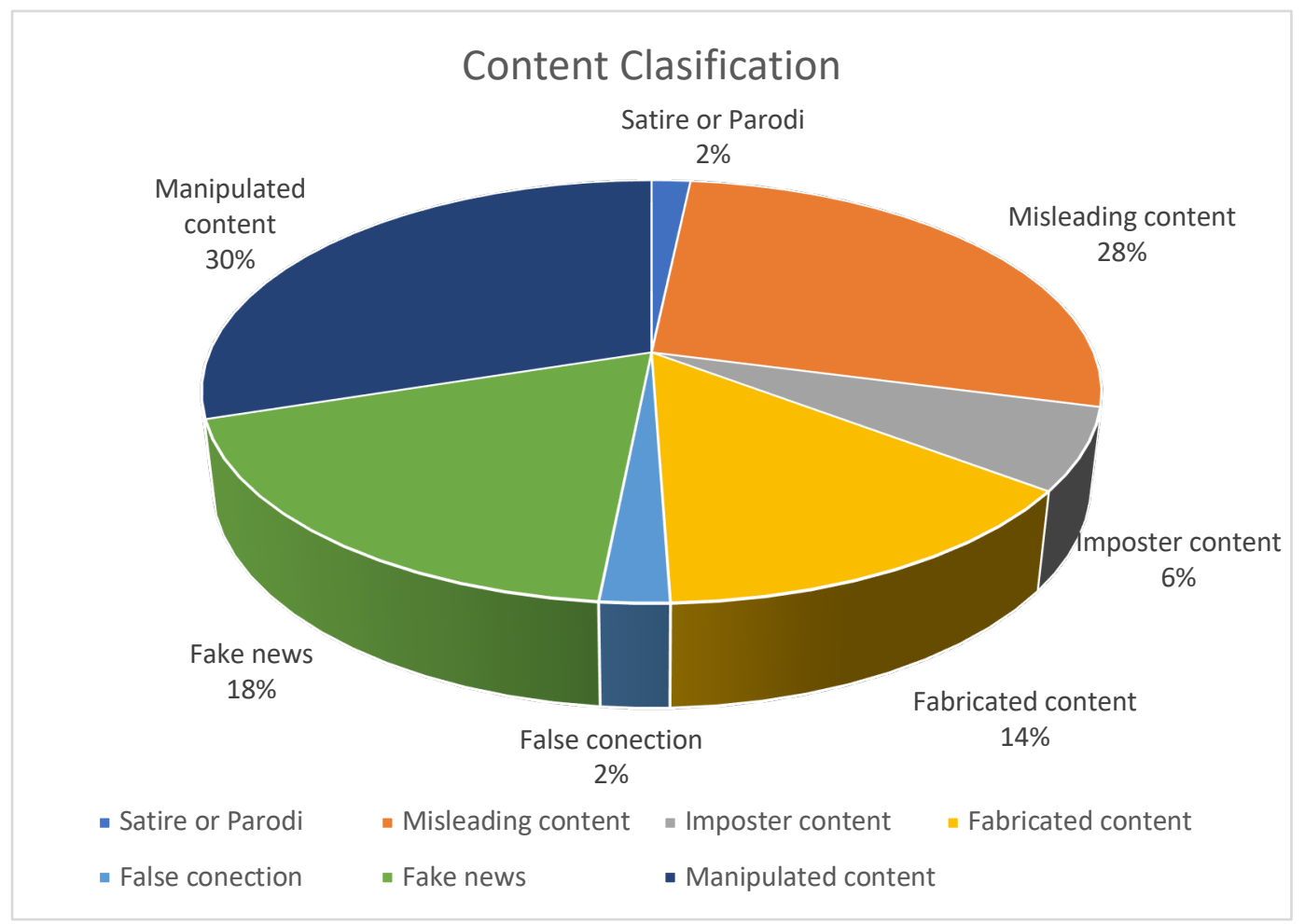

Figure 2. Content Clarification Based on Kind of Hoaxes

according to analysis unit, by classifying the elements by number, analyzing contents, and then finding the meaning of each of descriptions. This study mapped digital literacy educational content in Instagram @jabarsaberhoaks to anticipate the spread of hoax news in West Java. Identification of posts on@jabarsaberhoaks Instagram account throughout 2020 found 900 posts from January 1 to December 31, 2020.

\section{Result and Discussion}

West Java Hoax Buster (Jabar Saber Hoaks) is an official channel established by the West Java Provincial Government to verify information/news circulating in the public. The team routinely provides information and invites the public to actively participate in fighting fake news. The West Java Hoax Buster Team concluded that the number of social media users in Indonesia continue to increase. The rapid spread of information through social media, messaging applications, and other media affects the public in believing fake news. The rapid spread of information is not matched by the level of digital literacy among the public. Therefore, the West Java public needs a trusted channel to verify the information they receive. West Java Hoax Buster provides education on the wise use of social media and services to clarify and fact check issues and information circulating in the public. West Java Hoax Buster makes several efforts to educate all components of the public through several forms of activity, including socialization, counseling, training, fulfilling invitations as resource persons, and utilizing social media. In general, socialization can encourage the public to participate in the interests of their social life.

The information socialized to the public includes values, norms, roles, socializing ways, learning process, individuals, institutions, mass media, individuals, and groups. The general function of socialization can be seen from two perspectives: Individual point of view Socialization functions as a means of introduction, recognition, and adjustment to values, norms, and social structures. With this, an individual can become a good community member. Good people are citizens who meet the general expectations of other citizens. Secondly, socialization functions as a means of preserving, disseminating, and inheriting social values and norms. Values and norms are maintained from generation to generation in the public. With the function running, the purpose of socialization is that everyone can live well in the public if they have values and norms in life. Everyone can adapt their behavior to the expectations of the public with a culture that binds its citizens. Everyone can be aware of their existence in the public to play an active and positive role in everyday life. Everyone is capable of being a good member of the public. Community integrity can occur if citizens interact with each other well. The interaction is 
based on their respective roles. We must work together on research and experiment-driven solutions to reduce hoaxes and significantly improve information literacy (Wardle \& Derakhshan, 2017). This is what @ Jabasaberhoaks does in conducting information literacy education by providing examples of news cases that are misinformation and disinformation as shown in Figure 2.

In this analysis, the types of hoax are classified into seven categories according to the analysis unit. Based on the classification, the most common types in four primary categories in sequence are manipulated content $(30 \%)$, misleading content $(28 \%)$, fake news $(18 \%)$, and fabricated content (14\%). In 2014, the World Economic Forum identified the rapid spread of digital misinformation/ disinformation as one of the ten greatest dangers to the public. Therefore, since 2016 concerns about the authenticity of information have been found globally. Fake news discredits accurate information and is not profitable, takes the form of politicized falsehoods and lies that are widely spread on the internet and social media. Its emergence in the world of digital media, and especially social media, is a new phenomenon. (Howard \& Neudert, 2021) Researchers will explore more deeply about four dominant contents that appear in the object of research because they have similarities in objectivity and balanced impartiality. Two-dimensional problems of manipulated content are financial motives and motives influencing political meaning. (Tandoc et al., 2018) Fake news has also been used to manipulate authentic images or videos to create a false narrative. Image manipulation had evolved when the phenomenon of digital photos emerged, image editing software both with simple and complex techniques. (Zubiaga \& Ji, 2014) Figure 3 shows that misinformation about health with manipulated content type still dominates compared to other types such as economics, politics, crime, and education. It is easy to find manipulated information or news related to health, such as medicines, public health issues, and vaccines, during the COVID-19 pandemic like today. This is related to misinformation that can cause people not to take actions that are needed for health care. Disinformation is not a new issue in the world of health. This type of news presents a severe risk, especially for public health and public behavior. Public health is at risk of exposing patients to misleading information. This, of course, will affect health

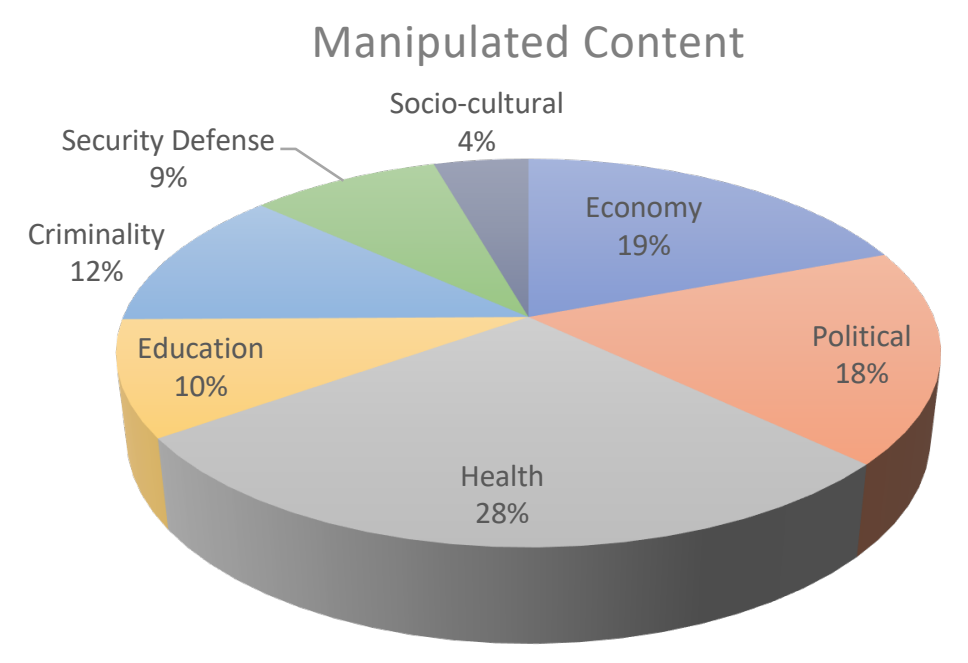

Figure 3. Manipulated Content (Source: Result Study in 2021)

which is described as follows:

\section{Manipulated content}

Manipulating content creators have the intention to provide misinformation. False information is created and published on websites, blogs, or social media platforms. Readers find it difficult to distinguish fake news 


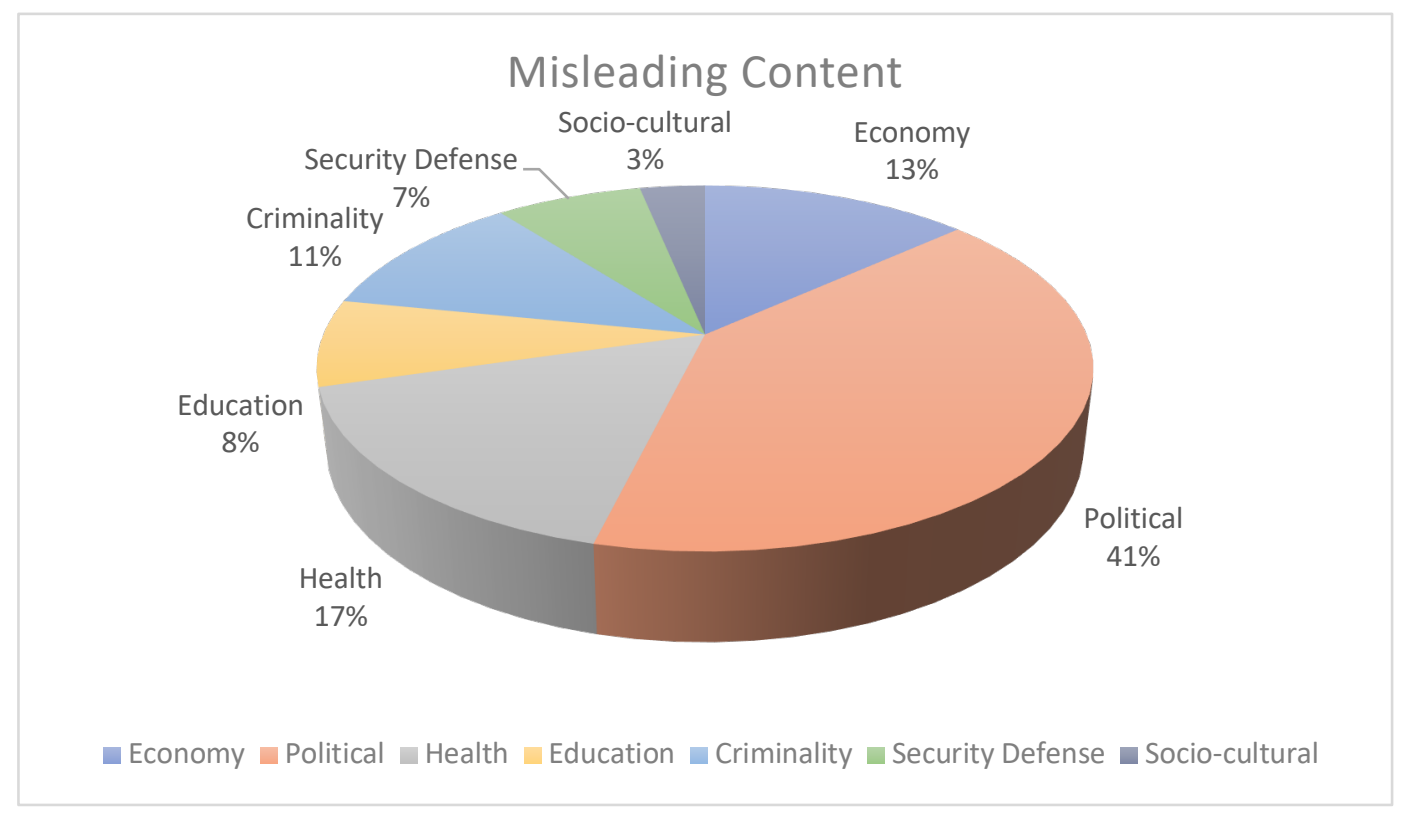

Figure 4. Misleading Content (Source: Result Study in 2021)

literacy and spread medical conspiracy theories. In the end, it indeed becomes a severe threat to public health because it can influence people's behavior (Bafadhal \& Santoso, 2020).

Information about health being manipulated in hoax news has increased in recent years. The Digital epidemic of disinformation has spread across the world. Digital media has become a tool to spread misinformation about health. The first months of a pandemic, for example, fighting online disinformation, are just as crucial as ensuring the availability of much-needed medical equipment for healthcare workers. Countries around the world are taking health literacy actions about COVID-19. Implement measures such as (a) guiding social media companies in removing controversial pandemic content, (b) establishing a particular unit to combat disinformation, and (c) criminalizing dangerous coronavirus fakes, including those related to public health measures (Radu, 2020).

The misinformation phenomenon about health develops at a higher pace that many people choose to get health information online. Health-related topics continue to be targets of misinformation. Various types of health misinformation include tobacco safety, vaccines, and even HIV stigmatization. Health communication as an academic discipline has been encountered with the challenge of stemming the flow of misinformation and educating individual beliefs about accepting misinformation. Misinformation about health gave birth to the term "Health Mis-literacy." Health communication challenge lies in ensuring the accuracy of messages shared online. (Krishna \& Thompson, 2021) Parker noted that health literacy levels, with high levels of health literacy, tend to be active consumers of online information.

In contrast, those with low levels of health literacy are the opposite. Recent studies have found that those with low levels of knowledge about health issues such as childhood vaccines are motivated to spread misinformation to others. Based on our understanding of health literacy, such individuals would be perceived as having low levels of health literacy knowledge, given a receipt of misinformation, but motivated to talk about their health opinions with others, contrary to expectations about those with low levels of health literacy. (Parker et al., 2003)

\section{Misleading Content}

Generally, misleading content is formed by utilizing original information, such as images, official statements, or statistics but edited so that it has no connection with the original context. West Java Hoax Buster in educating the public, conveying information that many misleading contents that are circulating that are harmful. Based on Figure 4, of 900 hoax posts in 2020, the most common themes found were political themes, around $41 \%$, this theme dominates, even double the number of health themes related to COVID-19.

In politics, actors usually use misleading information as political propaganda to quickly 


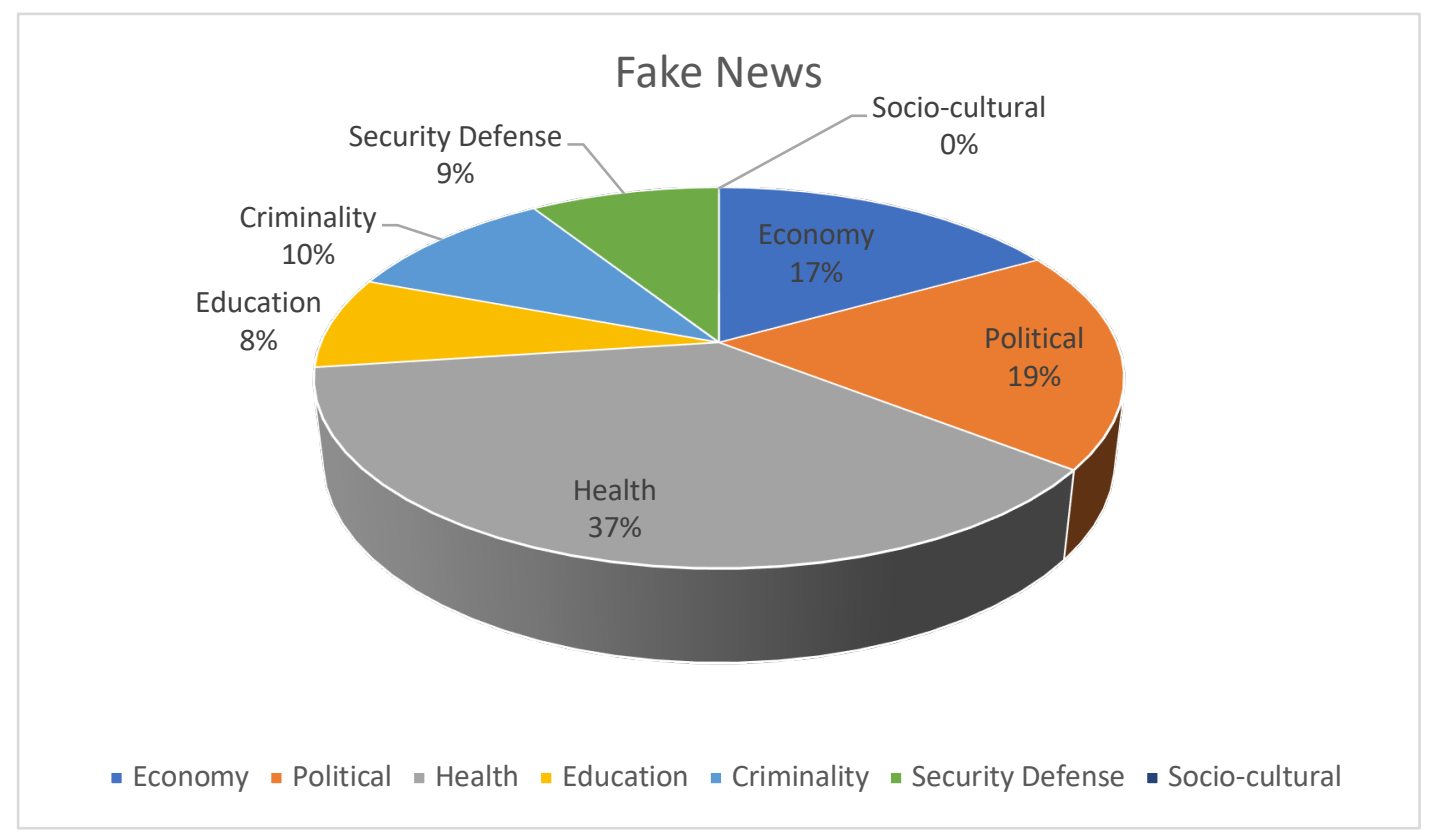

Figure 5. Fake News (Source: Result Study in 2021)

indoctrinate voters, form opinions, manipulate emotions/psychologically, and increase or decrease the quality of political candidates during general elections. Besides influencing the public, misleading information is also used to change negative images into positive ones or vice versa to increase the electability and popularity of supported candidates. Misleading content often contains tribal, religious, racial and societal group (SARA), personality, using a pattern of nicknames, transfers, lures, populist narratives, using news/information content carrying lies, and that is shared through all media, especially new media as a tool to weaken public perception. (Tahir et al., 2020) In Instagram analyze @jabarsaberhoaks, this account educates the public that rises phenomenon in social media public and becomes a tool of political interest and is often misused to grab people's attention and sympathy, political hoaxes are used as propaganda to provoke people to be influenced by news content. Even though social media should carry out literacy for the Indonesian public to be literate about politics and know their rights and obligations in the political field, it is no wonder that the most widely circulated hoax issue on social media from Indonesia is politics, there is a tendency that political hoaxes have a stimulating effect on the community (Prajarto, 2021).

\section{Fake News}

Fake news imitating media news has become a significant threat to the public around the world. The phenomenon of fake information or misleading always has a role in the human public all the time. However, the internet and social media proved to be fertile ground for fake news. For example, a new article by Vosoughi et al. (2018) shows that stories declared 'false' by many fact-checking organizations spread farther, faster, and more profound than any other type of news content. One factor of interest is that, even though the problem of fake news generally penetrates the political spectrum, fake news is more dominant among conservative audiences than liberals. (van der Linden et al., 2020).

Figure 5 shows that fake news clarification about health thing hoax at most (37\%) compared with fake news in other fields. Hoaxes about health are as dangerous as political and religious hoaxes. Health hoaxes can have a fatal impact on human health, whether it is about health therapy and improper use of drugs, and public perceptions and mindsets in carrying out daily activities during a pandemic. During the pandemic, fake news about Covid-19 was very large, both about misunderstandings in dealing with outbreaks and vaccines. Mafindo argues that there is a correlation between various vaccine hoaxes and the rejection of some people against vaccination efforts from the government because the public gets wrong information, so they tend to make 


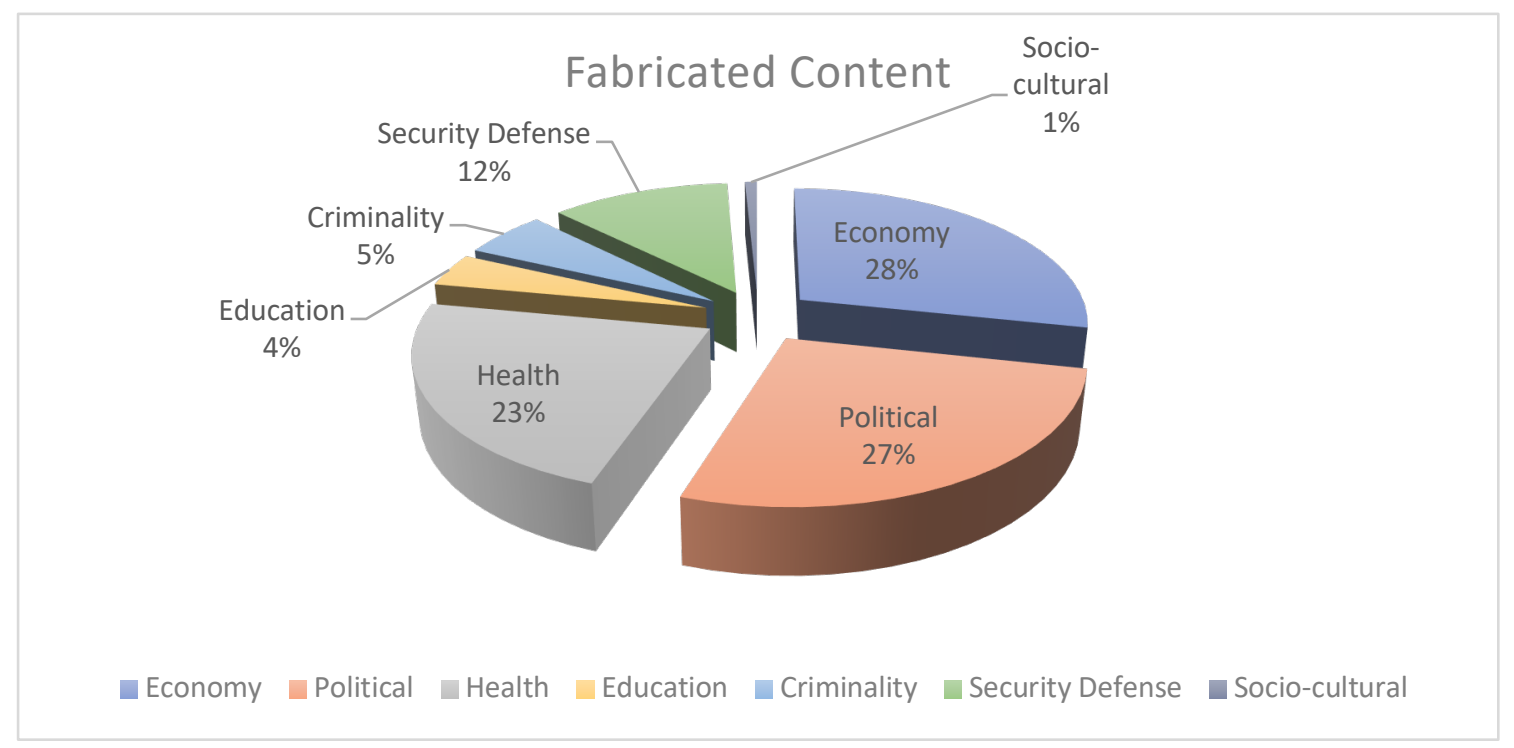

Figure 6. Fabricated Content (Source: Result Study in 2021)

wrong decisions. (Natasya, 2019) Health hoaxes tend to have a conative effect that health hoaxes tend to have an information function. (Prajarto, 2021)

Hoaxes in the health sector cannot be accounted for because they have unclear sources and are spread freely through social media and instant messages (Juditha, 2019). False health information spreads faster through social media than accurate information. Dissemination of misinformation about health, whether intentionally or unintentionally, has a significant impact on society and individuals. (Hill, 2019) As emphasized in a study, hoaxes in the health sector are health information that cannot be justified and are very detrimental to those who believe in them, so there are sanctions or penalties for those who spread hoaxes about health because they are considered to hinder the duties of health workers. (Haikal, 2020)

\section{Fabricated Content}

Fabricated content is considered to be the most dangerous type of fake content. This content was created with $100 \%$ content and cannot be justified. (Howard \& Neudert, 2021) The fabricated content (Figure 6) in research data is dominated by hoaxes about the economy $(28 \%)$, politics $(27 \%)$, and health $(23 \%)$. These three themes are very vulnerable to news that is deliberately made to deceive the public. In this context, content is usually blogs, images, or videos intentionally created and shared through social media. Speed and massive circulation of fabricated news make readers worried. This content is dangerous because information reaches personal smartphones in real-time. The educational goal of Jabarsaberhoaks through its Instagram is to understand that the public must recognize fabricated content from the start so that they are not provoked and stop the spread of this propaganda content (Bafadhal \& Santoso, 2020; Ilahi, 2019; Utami, 2019).

Fabricated content is another term for fake news. There are many reasons to use or create fabricated content, but frequently the intent is to mislead people for financial or political gain. During political elections today, for example, it is becoming the norm that different interest groups try to affect voters with fake news to steer them into a specific political or ideological direction (Wates, n.d.). Some of those who produce or distribute fabricated content do only for financial gain. Fake news websites created only for profit have been around for years. It should be underlined that we find it difficult to assess the true motivation of a particular agent. However, it is clear that the dominant motivation for creating fabricated content is financial gain. Fabricated content websites make money through advertising. While Google and Facebook have taken steps to prevent these sites from earning money through their ad networks. There are still many other networks where site owners can make money (Wardle \& Derakhshan, 2017).

Content fabrication requires a different response due to lack of facticity and intent to deceive. This type of information has no factual basis. However, stories are presented or published in the style of news articles to create legitimacy and are often trusted as a reliable source because partisan organizations often neutrally present information. Types of information are often disseminated for the 
purpose of financial gain by the creator (Tandoc et al., 2018). An interesting fact that Heil and Farhi point out is that the collection of fabricated materials cost almost $\$ 40,000$ to print and distribute, which signifies the level of intention and commitment planned to spread disinformation (W.Page, n.d.).

In the social media era, the period that claimed to be the "post-truth" era, misinformation in the media realm became increasingly rampant because mainstream media, cooperating with several elements in the social media arena, spread lies and half-truths, hoaxes, propaganda, and all kinds of fake news. Research that has been done reveals that there are significant differences between countries in the world regarding the type of news. In all countries, the topic of hoax news strongly reflects the agenda of national news setting. Online hoax news is not only a technologydriven phenomenon but also shaped by the national information The environment (Humprecht, 2019). Thus, dealing with misinformation threats, like fake news and all forms of information disorder that characterize the post-truth era requires the joint attention of stakeholders, including government, policymakers, media owners, professional media, and all lovers of democracy (Okoro \& Emmanuel, 2018).

Content on Instagram has the power to convey information to an audience. Therefore in optimizing this social media, readers can be invited to think critically about hoax phenomenon that develops in the public. So far, Instagram's role has only been seen as a medium that only functions as a forum for conveying provocative content with opposing tendencies. The study conducted by the researchers shows that Instagram as a social media helped explain to their followers about clarification of various hoaxes that developed in the public. @ Jabarsaberhoaks does this by providing education on digital literacy content. Instagram's potential to be used as an educational medium for the public and supported by other research which states that the use of Instagram as a medium of educational information is a new phenomenon that exists in use of social media, even social media continues to grow and is very common among young people today. (Pittman \& Reich, 2016) Educational information posted through accounts in photos, videos, or interactive talk has a positive response from its followers. The presence of an Instagram account becomes a reference medium in meeting needs, and even behavioral responses can be seen with changes in followers' attitudes. (Sari \& Basit, 2020) The use of Instagram affects learning creativity, especially teenagers, better use of Instagram, better creativity, and it happens the other way around. (Rubiyati et al., 2017) The experience felt by Instagram users as a form of learning communication is an experience that must continue to be honed so that the ability to understand visual media will increase by increasing visual literacy, which is very much needed because it can ward off fake news and can develop public abilities in digitalization era. The use of Instagram supported by visual literacy skills can encourage changes in attitudes, behavior, and cognition for better (Syah \& Darmawan, 2019).

On the other hand, Instagram has a lot of contents that do not educate, teach consumptive, and carry hedonistic, and provocative content. This is understandable if it is related to the analysis conducted by Vincent Mosco (Mosco, 2009) as the political economy in reviewing media content, including social media, there are forms of communication commodification. Commodification begins with content commodification in the context of this study. The author makes an analogy that media text includes social media content on Instagram. The message is constructed so that it can act as a product worthy of being sold in the market, able to generate profits and surplus value for content creators. Changing media texts into exchange values involves a complex process from social relations of content creators, endorsers, and even consumers (audience). Instagram content eventually becomes a product that contains certain symbols and images. Three forms of commodification can occur on Instagram accounts (1) Commodification of content when content is only based on or prioritizes commercial value in creating content (2) Commodification of audiences when the quality of Instagram is only judged by a large number of followers, (3) Commodification of human resources when content producers exploit individuals posted on Instagram in various styles and ways.

The findings in this study also focus on information about the number of types of hoaxes clarified by the @jabarsaberhoaks account. Hoax content dominance consists of manipulated content, misleading content, fake news, and fabricated content with health, political and economic themes. There are many types of misinformation/disinformation 
because every individual has the opportunity to do citizen journalism, such as participating in channeling activities and helping to share the news with the public. However, worriedness comes from an understanding of journalistic ethics in that many are trapped intentionally or unintentionally in making and spreading hoax news. Ironically, hoax news that spreads is believed to be accurate. The formation of public opinion leads to a stir in society, uncertainty of information, and creates fear in the masses. The research that has been done shows that the practice of citizen journalism is carried out on social media by several young people in Indonesia. They are aware of the importance of sharing information not presented by mainstream media and explain that Instagram can become a forum for exposure to information content to the public (Warikar, 2019).

\section{Conclusions}

In the new media era, hoaxes develop in all their forms in all areas of life, including economics, politics, culture, health, and defense and security. We cannot rely entirely on authorities to eradicate hoaxes on social media. Efforts made by all people, including the government, security forces, educational institutions, and even non-governmental organizations and communities involved in dealing with hoaxes will be in vain when the public does not participate in preventing hoaxes that appear in their environment. Form of public participation in fighting hoax contexts is to have digital literacy skills, this ability can be obtained formally or informally. A lot of information provides education about digital literacy in fighting hoaxes on legitimate official websites and social media. Implications of the results of this study emphasize that stigma against Instagram only has a negative impact that must be considered because, in reality, social media is also useful when used in creating positive content to educate the public, both formally and informally. This study still has a weakness because it only looks at the optimization side of social media messages and does not touch how the audience responds when they get information containing this hoax literacy education on Instagram. Thus, it will be more comprehensive if further research is also focused on the response and behavior of the audience in receiving this type of massage. When we know the audience's feedback after being exposed to hoax digital literacy of education information, it is hoped that it will be seen what kind of educational model should be used if we use social media to educate the public to be sensitive and wise in responding to hoax news on social media.

\section{Acknowledgements}

The researcher would like to thank LPPM Unisba which has provided funding for our research, as well as to our team of students who have collected data for research purposes at @jabarsaberhoaks. Thank you to the Department of Communication and Information Technology of West Java for accepting us as the location of our research.

\section{References}

Acuti, D., Mazzoli, V., Donvito, R., \& Chan, P. (2018). An Instagram content analysis for city branding in London and Florence. Journal of Global Fashion Marketing, 9(3), 185-204. https://doi.org/10.1080/20932685.2018.14 63859

Aldwairi, M., \& Alwahedi, A. (2018). Detecting fake news in social media networks. Procedia Computer Science, 141, 215-222. https://doi.org/10.1016/j.procs.2018.10.17 1

Atmoko, B. D. (2012). Instagram Handbook. Media Kita.

Aviani, M. N. (2020). Memberantas Hoaks Melalui Media Sosial (Studi Kasus pada AkunInstagram@jabarsaberhoaksdi Dinas Komunikasi dan Informatika Provinsi Jawa Barat) Skripsi Universitas Pendidikan Indonesia.

Bafadhal, O. M., \& Santoso, A. D. (2020). Memetakan Pesan Hoaks Berita Covid-19 Di Indonesia Lintas Kategori, Sumber, dan Jenis Disinformasi. Bricolage: Jurnal Magister Ilmu Komunikasi, 6(02), 235. https://doi.org/10.30813/bricolage.v6i02.2 148

Bungin, B. (2011). Penelitian Kualitatif (P. Media (ed.)). Prenada Media Group.

Cuervo Sánchez, S. L., Foronda Rojo, A., Rodríguez Martínez, A., \& Medrano Samaniego, C. (2019). Media and information literacy: a measurement instrument for adolescents. Educational Review. https://doi.org/10.1080/00131911.2019.16 46708 
Di Domenico, G., \& Visentin, M. (2020). Fake news or true lies? Reflections about problematic contents in marketing. International Journal of Market Research, 62(4), 409-417. https://doi.org/10.1177/147078532093471 9

Dimas, E. T., Akmal, A., Pusat, N., \& Komunikasi, K. (2017). Kajian Dampak Penggunaan Media Sosial Bagi Anak Dan Remaja.

Dimitrova, D. V., \& Bystrom, D. (2017). Role of social media in the 2016 Iowa caucuses. Journal of Political Marketing, 16(3-4), 386-406.

https://doi.org/10.1080/15377857.2017.13 45847

Edelman. (2019). 2018 Edelman Trust Barometer Special Report: Brands and Social Media. 28. www.edelman.ca/trust

Eriyanto. (2012). Analisis Framing: Komunikasi, Ideologi dan Politik Media. LKIS.

Fardiah, D., Rinawati, R., Darmawan, F., Abdul, R., \& Lucky, K. (2020). Media Literacy For Dissemination Anticipated Fake News On Social Media. Mediator: Jurnal Komunikasi, 13(2), 278-289. https://doi.org/10.29313/mediator.v13i2.6 624

Finneman, T., \& Thomas, R. J. (2018). A family of falsehoods: Deception, media hoaxes and fake news. Newspaper Research Journal, 39(3), 350-361. https://doi.org/10.1177/073953291879622 8

Fleming, C., \& O'Carroll, J. (2010). The art of the hoax. Parallax, 16(4), 45-59. https://doi.org/10.1080/13534645.2010.50 8648

Gumilar, G., \& Kusmayadi, I. M. (2017). Instagram Usage By Barstrad Community In Bandung City. Jurnal Komunikasi Ikatan Sarjana Komunikasi Indonesia, 2(2).

https://doi.org/10.25008/jkiski.v2i2.104

Haikal, H. (2020). Persepsi Masyarakat terhadap Hoax Bidang Kesehatan. Jurnal Manajemen Informasi Dan Administrasi Kesehatan (JMIAK), 3(2), 7-11. https://doi.org/10.32585/jmiak.v3i2.836
Hill, J. A. (2019). Medical misinformation: Vet the message! Journal of the American Heart Association, 8(3), 2-3. https://doi.org/10.1161/JAHA.118.011838

Hobbs, R. (2011). The state of media literacy: A response to potter. Journal of Broadcasting and Electronic Media, 55(3), 419-430.

https://doi.org/10.1080/08838151.2011.59 7594

Howard, P. N., \& Neudert, L. (2021). Digital misinformation/disinformation and children. August.

Humprecht, E. (2019). Where 'fake news' flourishes: a comparison across four Western democracies. Information Communication and Society, 22(13), 1973-1988.

https://doi.org/10.1080/1369118X.2018.1 474241

Ilahi, H. N. (2019). Women and Hoax News Processing on WhatsApp. Jurnal Ilmu Sosial Dan Ilmu Politik, 22(2), 98. https://doi.org/10.22146/jsp.31865

Juditha, C. (2019). Literasi Informasi Melawan Hoaks Bidang Kesehatan di Komunitas Online.

https://doi.org/10.24002/jik.v16i1.1857

Kasperek, S., \& Messersmith, B. (2015). The Library that Cried Wolf: Outcomes of a Banned Book Hoax on Facebook. Pennsylvania Libraries: Research \& Practice, 3(1), 53-75. https://doi.org/10.5195/palrap.2015.87

Kata, A. (2010). A postmodern Pandora's box: Anti-vaccination misinformation on the internet. Vaccine, 28(7), 1709-1716. https://doi.org/10.1016/j.vaccine.2009.12. 022

Kietzmann, J. H., Hermkens, K., McCarthy, I. P., \& Silvestre, B. S. (2011). Social media? Get serious! Understanding the functional building blocks of social media. Business Horizons, 54(3), 241-251. https://doi.org/10.1016/j.bushor.2011.01.0 05

Krishna, A., \& Thompson, T. L. (2021). Misinformation About Health: A Review of Health Communication and Misinformation Scholarship. American Behavioral Scientist, 65(2), 316-332. https://doi.org/10.1177/000276421987822 3 
Kurnia, N. D., Johan, R. C., \& Rullyana, G. (2018). Hubungan Pemanfaatan Media Sosial Instagram Dengan Kemampuan Literasi Media Di Upt Perpustakaan Itenas. Edulib, 8(1), 1. https://doi.org/10.17509/edulib.v8i1.1020 8

Lee, S., \& Kim, E. (2020). Influencer marketing on Instagram: How sponsorship disclosure, influencer credibility, and brand credibility impact the effectiveness of Instagram promotional post. Journal of Global Fashion Marketing, 11(3), 232249.

https://doi.org/10.1080/20932685.2020.17 52766

McDougall, J., Brites, M. J., Couto, M. J., \& Lucas, C. (2019). Digital literacy, fake news and education. Cultura y Educacion, $31(2)$ 203-212. https://doi.org/10.1080/11356405.2019.16 03632

Mosco, V. (2009). The Political Economy of Communication (2nd edition). SAGE Publications Ltd.

Muda, Z., \& Monggilo, Z. (2020). Analisis Konten Kualitatif Hoaks Dan Literasi Digital Dalam @Komikfunday. In Jurnal Ilmu Komunikasi (Vol. 9, Issue 1).

Natasya, M. (2019). Bikin Resah! Hoax Kesehatan Terbanyak Ketiga Setelah Hoax Politik dan Agam. Detik Health, 1. https://health.detik.com/beritadetikhealth/d-4754974/bikin-resah-hoaxkesehatan-terbanyak-ketiga-setelah-hoaxpolitik-dan-

agama?_ga $=2.84242142 .612556602 .1630$ 885040-1535097015.1617610352

Noviyanti, N. I. (2020). Instagram Social Media As Guidance And Counseling Media Based On Technology. International Journal of Applied Guidance and Counseling, 1(1), 16-19.

Nurlatifah, M. (2019). The Fight Against Hoax: An Explorative Study towards Anti-Hoax Movements in Indonesia. In Jurnal Komunikasi ISKI (Vol. 04, Issue 01).

Okoro, N., \& Emmanuel, N. O. (2018). Beyond Misinformation: Survival Alternatives for Nigerian Media in the "Post-Truth" Era. African Journalism Studies, 39(4), 67-90. https://doi.org/10.1080/23743670.2018.15 51810
Park, K., \& Rim, H. (2020). "Click First!": The Effects of Instant Activism Via a Hoax on Social Media. Social Media and Society, 6(2). https://doi.org/10.1177/205630512090470 6

Parker, R. M., Ratzan, S. C., \& Lurie, N. (2003). Health literacy: A policy challenge for advancing high-quality health care. Health Affairs, 22(4), 147-153. https://doi.org/10.1377/hlthaff.22.4.147

Pittman, M., \& Reich, B. (2016). Social media and loneliness: Why an Instagram picture may be worth more than a thousand Twitter words. Computers in Human Behavior, 62, 155-167. https://doi.org/10.1016/j.chb.2016.03.084

Prajarto, Y. N. (2021). Fact-Checking Practice Regarding Information of Covid-19 Pandemic on Tempo.co, Tirto.id, and Kompas.com. Jurnal Penelitian Komunikasi Dan Opini Publik, 25(1). https://doi.org/10.33299/jpkop.25.1.3461

Radu, R. (2020). Fighting the 'Infodemic': Legal Responses to COVID-19 Disinformation. Social Media and Society, 6(3). https://doi.org/10.1177/205630512094819 0

Rahmah, A. (2015). Digital Literacy Learning System for Indonesian Citizens. Procedia Computer Science, 72, 94-101. https://doi.org/10.1016/j.procs.2015.12.10 9

Rubiyati, Asrori, M., \& Wicaksono, L. (2017). Pengaruh Pemanfaatan Media Sosial Instagram Terhadap Kreativitas Belajar Pada Remaja Kelas VII. Jurnal Pendidikan dan Pembelajaran Khatulistiwa, 7(5), 1-8. http://jurnal.untan.ac.id/index.php/jpdpb/a rticle/download/25681/75676576765

Russo, A., Watkins, J., \& Groundwater-Smith, S. (2009). The impact of social media on informal learning in museums. Educational Media International, 46(2), 153-166.

https://doi.org/10.1080/095239809029335 32

Sari, D. N., \& Basit, A. (2020). Media Sosial Instagram Sebagai Media Informasi Edukasi. Persepsi: Communication Journal, 3(1), 23-36. https://doi.org/10.30596/persepsi.v3i1.442 8 
Shahbaznezhad, H., Dolan, R., \& Rashidirad, M. (2021). The Role of Social Media Content Format and Platform in Users' Engagement Behavior. Journal of Interactive Marketing, 53, 47-65. https://doi.org/10.1016/j.intmar.2020.05.0 01

Stanley J. Baran, D. K. D. (2010). Mass Communication Theory: Foundations, Ferment and Future. Belmot: CA, Wadsworth.

Swanepoel, G. P., \& Bruwer, A. (2020). Educating the always-on generation in an instant(gram) \#blendedlearning. Perspectives in Education, 38(1), 16-29. https://doi.org/10.18820/2519593X/PIE.V $38 \mathrm{I} 1.2$

Syah, R., \& Darmawan, D. (2019). Pemanfaatan Media Sosial Instagram Sebagai Literasi Visual Pada Pendidikan Orang Dewasa. Jurnal AKRAB!, 10(1), 71-80.

https://jurnalakrab.kemdikbud.go.id/jurnal akrab/article/view/276/219

Tahir, R., Kusmanto, H., \& Amin, M. (2020). Propaganda Politik Hoaks dalam Pemilihan Presiden Tahun 2019. Perspektif, 9(2), 236-251. https://doi.org/10.31289/perspektif.v9i2.3 458

Tandoc, E. C., Lim, Z. W., \& Ling, R. (2018). Defining "Fake News": A typology of scholarly definitions. Digital Journalism, 6(2), 137-153. https://doi.org/10.1080/21670811.2017.13 60143

Tsaniyah, N., \& Juliana, K. A. (2019). Literasi Digital Sebagai Upaya Menangkal Hoaks Di Era Disrupsi. Al-Balagh: Jurnal Dakwah Dan Komunikasi, 4(1), 121. https://doi.org/10.22515/balagh.v4i1.1555

Utami, P. (2019). Hoax in Modern Politics. Jurnal Ilmu Sosial Dan Ilmu Politik, 22(2), 85. https://doi.org/10.22146/jsp.34614

Van der Linden, S., Maibach, E., \& Leiserowitz, A. (2015). Improving Public Engagement With Climate Change: Five "Best Practice" Insights From Psychological Science. Perspectives on Psychological Science, 10(6), 758-763. https://doi.org/10.1177/174569161559851 6
Van der Linden, S., Panagopoulos, C., \& Roozenbeek, J. (2020). You are fake news: political bias in perceptions of fake news. Media, Culture and Society, 42(3), 460470. https://doi.org/10.1177/016344372090699 2

Veil, S. R., Sellnow, T. L., \& Petrun, E. L. (2012). Hoaxes and the Paradoxical Challenges of Restoring Legitimacy: Dominos' Response to Its YouTube Crisis. Management Communication Quarterly, 26(2), 322-345. https://doi.org/10.1177/089331891142668 5

W.Page, A. (n.d.). Ethical Implications of Fake News for PR Professionals. https://www.pagecentertraining.psu.edu/p ublic-relations-ethics/introduction-to-theethical-implications-of-fake-news-for-prprofessionals/lesson-2-fake-newscontent/fabricated-content-impostercontent/

Wahyudin, D., \& Adiputra, C. P. (2019). Analisis Literasi Digital Pada Konten Instagram@Infinitygenre. WACANA, Jurnal Ilmiah Ilmu Komunikasi, 18(1). https://doi.org/10.32509/wacana.v18i1.74 4

Wardle, C., \& Derakhshan, H. (2017). Information disorder: Toward an interdisciplinary framework for research and policymaking. Council of Europe Report, $1-108$. $\mathrm{https} / / / \mathrm{rm}$. coe.int/information-disordertoward-an-interdisciplinary-frameworkfor-researc/168076277c

Warikar, E. F. (2019). Citizen Journalism Dan Instagram (Studi Kasus Praktik Citizen Journalism Melalui Instagram oleh Generasi $Y$ di Indonesia) [Universitas Atmajaya Yogyakarta]. http://ejournal.uajy.ac.id/id/eprint/18552

Wates, W. (n.d.). Evaluating Information. Dominican University. https://research.dom.edu/c.php?g=106667 $6 \& p=788153$

Yuliarti, M. S., Siagian, M., \& Wardaningtyas, A. K. (2020). Network Society and Social Movement: Message Reception among Instagram Users. Jurnal Komunikasi Ikatan Sarjana Komunikasi Indonesia, $5(2)$.

https://doi.org/10.25008/jkiski.v5i2.382 
Zubiaga, A., \& Ji, H. (2014). Tweet, but verify: epistemic study of information verification on Twitter. Social Network Analysis and
Mining,

4(1),

$1-12$.

https://doi.org/10.1007/s13278-014-0163- $\mathrm{y}$ 